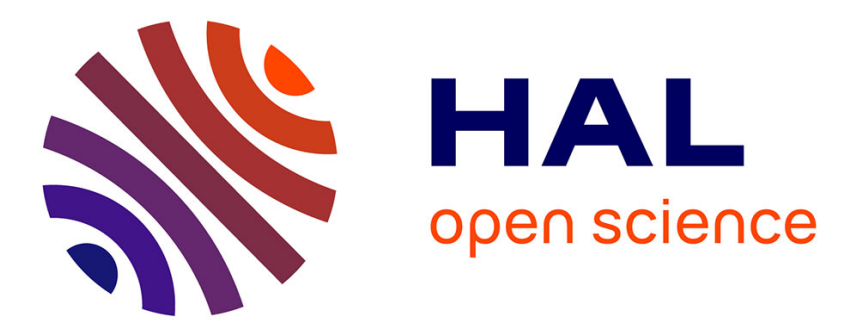

\title{
Lipase catalyzed esterification of formic acid in solvent and solvent-free systems
}

Abdulhadi Aljawish, Egon Heuson, Muriel Bigan, Rénato Froidevaux

\section{To cite this version:}

Abdulhadi Aljawish, Egon Heuson, Muriel Bigan, Rénato Froidevaux. Lipase catalyzed esterification of formic acid in solvent and solvent-free systems. Biocatalysis and Agricultural Biotechnology, 2019, 20, 10.1016/j.bcab.2019.101221 . hal-02620582

\section{HAL Id: hal-02620582 \\ https://hal.inrae.fr/hal-02620582}

Submitted on 25 Oct 2021

HAL is a multi-disciplinary open access archive for the deposit and dissemination of scientific research documents, whether they are published or not. The documents may come from teaching and research institutions in France or abroad, or from public or private research centers.
L'archive ouverte pluridisciplinaire HAL, est destinée au dépôt et à la diffusion de documents scientifiques de niveau recherche, publiés ou non, émanant des établissements d'enseignement et de recherche français ou étrangers, des laboratoires publics ou privés.

\section{(ㄷ)(1) $\$$}

Distributed under a Creative Commons Attribution - NonCommerciall 4.0 International 


\section{Lipase catalyzed esterification of formic acid in solvent and solvent-free systems}

Abdulhadi Aljawish*, Egon Heuson, Muriel Bigan and Renato Froidevaux*

Univ. Lille, INRA, ISA, Univ. Artois, Univ. Littoral Côte d'Opale, EA 7394, ICV - Institut Charles Viollette, F-59000 Lille, France

\section{Abstract}

Esterification reaction between formic acid and alcohols $(\mathrm{C} 4, \mathrm{C} 8)$ catalyzed by lipases was performed in solvent and solvent-free systems. High Performance Liquid Chromatography (HPLC) was used to study the kinetic parameters (Michaelis-Menten) and the reaction conditions by monitoring the ester synthesis. The optimal conditions for formate ester synthesis were found to be: $0.5 \mathrm{M}$ of formic acid, $1.5 \mathrm{M}$ of alcohol, $2 \%$ of Novozym 435 at $40^{\circ} \mathrm{C}$ and $400 \mathrm{rpm}$ in acetonitrile solvent without molecular sieves. In solvent-free system, the optimal conditions were found to be: $1 \mathrm{M}$ of formic acid, $10 \mathrm{M}$ of alcohol, $2 \%$ of Novozym 435 at $40^{\circ} \mathrm{C}$ and $400 \mathrm{rpm}$ without molecular sieves. These optimal conditions resulted in maximum ester yield about $90 \%$ for $8 \mathrm{~h}$ in solvent system and $5 \mathrm{~h}$ in solvent-free system. Among all esterification reactions, the esterification reaction of formic acid with octan-1-ol in solvent-free system was the better regarding the quantity of esterified formic acid, catalytic efficiency of lipase and the required reaction time. Under these optimal conditions, the biocatalyst could be reused for six reaction cycles keeping around $97 \%$ of its initial activity after treatment process with n-hexane. Consequently, this enzymatic procedure in solvent-free system could provide formate esters for food and cosmetic applications.

Key-words: Esterification, lipase, formic acid, glycerol, solvent-free system

Corresponding author. Tel.: +33 (0)320417566; Fax: +33 (0)383 595772

*E-mail address: Renato.froidevaux@univ-lille.fr (R. Froidevaux) ahjawish@yahoo.com (A.Aljawish) 


\section{Introduction}

In the context of the valorization of biomass, the glycerol, a co-product of biodiesel production, could be transformed into a mixture of carboxylic acids (glycolic, glyceric, formic, lactic, tartronic and oxalic) using chemical catalysts (Skrzynska et al., 2016a; Skrzynska et al., 2016b). One of different strategies proposed to recovery and valorize those carboxylic acids is their transformation into esters by esterification reaction. As the formic acid is a major acid in the mixture of carboxylic acids produced from the chemical oxidation of glycerol, the esterification reaction of formic acid with alcohols was investigated in this article.

Esters are widespread in nature as responsible compounds for the aroma of many fruits such as bananas, strawberries... (Riemenschneider and Bolt, 2005). In industry, these compounds have attached attention for their various uses as aroma, emulsifying agents, humectants... in food, perfumery, chemical, cosmetic and pharmaceutical applications (Almeida et al., 2007; Nurdock, 2010). For example, formate esters have been used as favors in industrial applications (Nurdock, 2010). Butyl formate has a fruity, plum-like odor and corresponding taste and $n$-octyl formate has a fruity odor with a rose-orange note and a bitter flavor, refreshingly fruity green at low concentrations (Nurdock, 2010). Recently, formate esters such as octyl formate was used by formate dehydrogenase as a reactive solvent to regenerate NADH from NAD ${ }^{+}$(Frohlich et al., 2011; Janssen et al., 2014).

Among the approaches used in the synthesis of esters, the esterification and transesterification are considered as the most common. These processes are usually performed by reaction between electrophiles (acyl donor) such as acids or esters and nucleophiles (acyl acceptor) such as alcohols, esters using chemical or enzymatic catalysts in organic or aqueous media (Khan and Rathod, 2015). Due to the growing safety and environmental concerns, the 
synthesis of esters using enzymes was constantly investigated as an attractive alternative to toxic, environmentally unfriend and non-specific chemical approaches (Khan et al., 2015). Indeed, the enzymatic synthesis of esters has gained interest because of the mild reaction conditions and its high catalytic efficiency. Among the enzymes used in the synthesis of esters, lipases were successfully used to catalyze esterification and transesterification reactions of different carboxylic acids that contain at least one hydroxyl or acid group as described by several studies (Aschenbrenner et al., 2009; Mirzarakhmetova, 2012).

Lipases are known as triacylglycerol ester hydrolases, EC 3.1.1.3. They are versatile enzymes, mainly used to hydrolyze ester bonds of triacylglycerols (oils and fats) and to release fatty acids, diacyglycerols, monoacylglycerols and glycerol. Lipases, under certain conditions such as lack of water or presence of nucleophilic molecules "alcohols" in reaction medium, are able to catalyze the reverse reactions (esterification and transesterification) (Bornscheuer, 2002). Indeed, the ester formation can be performed directly by the acid esterification in the presence of alcohol with a generated water molecule as a co-product or indirectly by the transesterification reactions of esters with alcohol (alcoholysis), with acids (acidolysis) or with other esters (interesterification) without a produced water molecule (Gunstone, 1999). The lipase-catalyzed ester synthesis usually occurs in organic medium with minimal amount of water that is necessary to polarize reactive groups in the active site and on the surface of the enzyme. The presence of water especially influences reactivity in acyl transfer reactions. Generally, lipases require low amount of water in reaction medium to keep their activity and catalyze the synthesis reaction (Kremnicky et al., 2004).

Several studies have reported the ester synthesis from carboxylic acids such as lactic, malic, glycolic, glyceric and acetic acids with different nucleophiles such as alcohols, esters, and fatty acids in the presence of low amount of water almost $1 \%$ in organic medium (hexane, 
acetonitrile...) or solvent-free system (Kiran et al., 2000; Martins et al., 2013; Mirzarakhmetova, 2012; Park et al., 2001; Roenne et al., 2005; Sundell and Kanerva, 2014; Torres et al., 1999a; Torres and Otero, 1999b; Torres and Otero, 2001). Up to now, the enzymatic synthesis of formate esters were only performed either by lipase-catalyzed transesterification reaction of ethyl formate to octyl formate (Janssen et al., 2014) or by transformation reaction of aliphatic aldehydes into alkyl formates using monooxygenase from Aspergillus flavus (Ferroni et al., 2017). Consequently, the direct enzymatic synthesis of formate esters from formic acid (C1) by esterification reaction was not yet reported in the literature.

In the context of carboxylic acids valorization produced from the chemical oxidation of glycerol, a co-product of biodiesel production, the esterification reaction of formic acid, the major produced carboxylic acid, with two alcohols (butan-1-ol and octan-1-ol) was performed by lipases in organic solvent and in solvent-free system. The reaction parameters such as temperature, reaction medium, molar ratio (acid: alcohol), acid concentration, biocatalyst charge, water content, alcohol chain length, shaking speed, molecular sieves, carbon accounting/material balance and reaction time, as well as Michaelis-Menten kinetic parameters (Km, Vmax, Kcat), were studied. Finally, the stability and the recycling of lipase enzyme for multiple batches were tested.

\section{Materials and methods}

\section{II.1. Chemicals and Enzymes}

Formic acid, butan-1-ol, octan-1-ol and acetonitrile were purchased from Sigma-Aldrich (France) with purity over than 97\%. Immobilized lipases (Novozym 435 from Candida antarctica, Novolime ${ }^{\circledR}$, Lipozym $^{\circledR}$ RM IM from Rhizomucor meihei, Lipozym ${ }^{\circledR}$ TL IM from 
Thermomyces lanuginosus) and Free lipases $\left(\right.$ Novozym $^{\circledR}$ 40116; EversaTranform; Callera ${ }^{\circledR}$ Trans; Patalase ${ }^{\circledR}$ 2000L; Lipozym ${ }^{\circledR}$ TL from Mucor meihei) were purchased from Novozymes (France). Immobilized lipase (Lipase acrylic resin from candida Antarctica; Lipase from Candida rugose) and free lipases (Lipase from Rhizomucor miehei; Lipase from Thermomyces langinosus; Lipase from Aspergillus niger) were purchased from SigmaAldrich (France). Immobilized lipase (Lipase B from Candida antarctica immobilized on ECR1030M (CalB immo plus); L. Lifetech ${ }^{\mathrm{TM}}$ ECR 8204F) purchased from Purolite (United Kingdom). All other chemicals were analytical grade.

\section{II.2. Lipase activity}

The lipase activity was determined using a spectrophotometric method based on monitoring the hydrolysis of $p$-nitrophenyl acetate (p-NPA) to p-nitrophenyl (p-NP), a yellow compound quantified by the absorbance at $400 \mathrm{~nm}$ as according to the method of Barros with some modifications (de Barros et al., 2009). The reaction medium ( $1 \mathrm{ml}$ ) is composed of $10 \mu \mathrm{l}$ of p-nitrophenyl acetate $(50 \mathrm{mM})$ and of $990 \mu \mathrm{L}$ of sodium phosphate buffer $(100 \mathrm{mM}, \mathrm{pH}$ 7.2). The reaction was started by adding $5 \mathrm{mg}$ of immobilized enzyme or $5 \mu \mathrm{l}$ of free enzyme at $37^{\circ} \mathrm{C}$. The blank reaction was prepared without nitrophenyl acetate. One unit of lipase activity is defined as the amount of enzyme required to release 1 nanomole $\left(10^{-9} \mathrm{~mol}\right)$ of $\mathrm{p}$ nitrophenyl per minute at $\mathrm{pH} 7.2$ and $37^{\circ} \mathrm{C}$ using p-nitrophenyl acetate as substrate.

Activity $\left(\right.$ nanomole $\min ^{-1} \mathrm{~mL}^{-1}($ Units $/ \mathrm{ml})=$

$$
\left[\left(\Delta \mathrm{A}_{400 \mathrm{~nm}} / \mathrm{min} \text { Test }-\Delta \mathrm{A}_{400 \mathrm{~nm}} / \mathrm{min} \text { Blank }\right)(\mathrm{df})\right] /[(0.0148)(0.005)]
$$

df: Dilution factor

0.0148: Micromolar extinction coefficient of p-nitrophenyl at $400 \mathrm{~nm}$ 
The enzymatic activity of each enzyme using the spectrophotometric method based on monitoring the hydrolysis of p-nitrophenyl acetate (p-NPA) to p-nitrophenol (p-NP) was shown in Table 1 . The results showed that all immobilized enzymes are more effective than 122 free enzymes.

\section{II.3. Esterification reaction}

The substrates (butan-1-ol or octan-1-ol and formic acid) were dissolved in organic solvent at different molar ratios. In organic solvent, the reaction was carried out in a glass tube (working volume of $5 \mathrm{ml}$ ) under atmospheric conditions at $50^{\circ} \mathrm{C}$ and $700 \mathrm{rpm}$ for $24 \mathrm{~h}$. The reaction was started by adding $2.5 \%(\mathrm{w} / \mathrm{v})$ of enzyme. In solvent-free system, the formic acid was directly dissolved in the alcohol used as nucleophile and reaction medium under the same reaction conditions as previously described in organic solvent. Two controls without lipase were performed under the same reaction conditions in organic solvent and in solventfree system. Samples were taken at different time intervals to follow the ester formation using high performance liquid chromatography. Before analysis, samples were carefully filtered with Minstar-RC membranes (Sartorius porosity $0.2 \mu \mathrm{m}$ ). Each analysis was made in triplicate.

\section{II.4. Analysis of reaction mixtures}

To monitor the ester formation, reaction mixtures were analysed using High Performance Liquid Chromatography (HPLC) (Shimadzu Class-VP HPLC system with computer-controlled system containing upgraded Class-VP 6.1 software). For analysis the 
Detector (RID) and Photodiode Array Detector (UV). The elution was performed using an isocratic method of solvent A: water/sulphuric acid (100:0.06; v/v) and solvent B: acetonitrile (42:58, respectively) at a flow rate of $0.5 \mathrm{ml} / \mathrm{min}$ during $15 \mathrm{~min}$. The injection volume of sample was of $10 \mu \mathrm{l}$. The ester yield is calculated as following:

\section{Ester yield $(\%)=[$ ester concentration/initial acid concentration $] \times 100$}

\section{II.5. Enzyme kinetics and substrate specificity}

The $\mathrm{Km}$ value and maximum velocity (Vmax) (Michaelis-Menten kinetic parameters) of lipase B (Novozym 435) were determined by a Lineweaver-Burk plot. For that, different concentrations from 0.1 to $0.5 \mathrm{M}$ of formic acid were esterified with two alcohols (butan-1-ol, octan-1-ol) in solvent and solvent-free system by lipase enzyme at $50^{\circ} \mathrm{C}$. Substrate specificity $(\mathrm{Vmax} / \mathrm{Km})$ which determine enzymatic affinity towards formic acid was calculated by the data obtained from the above plot (Lineweaver and Burk, 1934).

\section{II.6. Water content measurement}

Water content was determined by the Karl Fischer method using a KF DL18 Mettler Toledo apparatus (Barcelona, Spain). Water content of the reaction mixtures were determined by titration. A blank consisting solely of acetonitrile was used to eliminate errors associated with the water content of the acetonitrile.

\section{II.7. Carbon accounting and Material balance}

To check if all carbons of acid and alcohol introduced in the esterification reaction contributed at the ester synthesis and there are not second reactions or lost carbon, the carbon accounting and material balance were calculated as following: 
[(carbon number of ester $\mathrm{x}$ its concentration) / (carbon number of transformed acid $\mathrm{x}$ its concentration $)+($ carbon number of transformed alcohol x its concentration $)] \times 100$

$[(\mathrm{Mw}$ of transformed acid $\mathrm{x}$ its concentration $)+(\mathrm{Mw}$ of transformed alcohol $\mathrm{x}$ its concentration $) /(\mathrm{Mw}$ of formed ester $\mathrm{x}$ its concentration $)+(\mathrm{Mw}$ of formed water $\mathrm{x}$ its concentration)] x 100

\section{II.8. Lipase stability and re-use}

The stability of lipase was studied under the reaction conditions as previously described.

171

172

\section{II.9. Statistical analysis}

The experimental results were performed in triplicate. The data were recorded as means \pm standard deviation (SD) and analyzed by SPSS (version 11.5 for Windows 2000, SPSS Inc.). One-way analysis of variance was performed by ANOVA procedures. Significant 
differences between means were determined by Duncan's Multiple Range tests. Differences at $p<0.05$ were considered significant.

\section{Results and discussion}

\section{III.1. Esterification reaction in solvent medium}

\section{III.1.1. Influence of reaction medium}

The esterification reaction of formic acid with butan-1-ol was performed in different solvents to study their influence on the ester synthesis. In this series of experiments, molar ratio (1:1) of formic acid and butan-1-ol was used. Lipase Novozym 435 was used as a biocatalyst because it is more common enzyme to catalyze the reaction esterification. Reaction medium (5 ml) was composed from formic acid (0.2 M) and butan-1-ol (0.2 M). The ester synthesis was started by adding $2.5 \%(\mathrm{w} / \mathrm{v})$ of immobilized lipase Novozym 435 at 700 $\mathrm{rpm}$ and $50^{\circ} \mathrm{C}$ for $24 \mathrm{~h}$. In this experiment, four solvents (n-hexane, acetonitrile, acetone and 1,4-dioxane $)$ with $\log P(3.5,-0.33,-0,24,-1.1$ respectively $)$ were tested. Results demonstrated that the esterification reaction in acetonitrile achieved the best yield of ester (about $73 \%$ ) in comparison with the ester yield in other solvents as shown in Figure 1. This result is in accordance with previous results obtained by Torres et al. who found that acetonitrile used as reaction medium achieved the best yield of ester between lactic acid and dodecanol, compared to the other solvents (hexane, acetone, 1,4-dioxane). This result can be due to the high solubility of formic acid in acetonitrile in comparison with other solvents (Torres et al., 1999b).

\section{III.1.2. Screening of enzymes}

Various lipases (immobilized and free) were screened for their catalytic efficiency in the esterification reaction between formic acid and butan-1-ol (Table 2). Reaction mixtures were 
composed of $0.2 \mathrm{M}$ of formic acid and $0.2 \mathrm{M}$ of butan-1-ol in $5 \mathrm{~mL}$ of acetonitrile. The reaction was started by adding $2.5 \%(\mathrm{w} / \mathrm{v})$ of immobilized lipase or $2.5 \%(\mathrm{v} / \mathrm{v})$ of free lipase at $50{ }^{\circ} \mathrm{C}$ for $24 \mathrm{~h}$. Among tested lipases, three immobilized lipases and one free lipase could only catalyze the esterification reaction. The highest yield of ester was obtained using Novozym 435 as shown in Table 2. This result is in accordance with previous results reported on the esterification reaction between carboxylic acids such as lactic acid and alcohols such as hexadecanol (Roenne et al., 2005) or fatty acids such as caprylic acid (Torres et al., 2001) where Novozym 435 gave the best yields of ester production.

\section{III.1.3. Effect of formic acid:butane-1-ol molar ratio}

The molar ratio between formic acid and butan-1-ol was varied while the other parameters were held constant at $50^{\circ} \mathrm{C}$ for $24 \mathrm{~h}$. The concentration of $0.1 \mathrm{M}$ for both substrates was used for a ratio of $1: 1$. Firstly, the acid concentration was held constant at $0.1 \mathrm{M}$ while the alcohol concentration increased to obtain a ratio of $1: 5$ and vice versa to obtain a ratio of 5:1. Figure 2 shows that 1:3,1:4, 1:5 are the favorable ratios, yielding about $93 \%$ of ester. In previous study, it was found that the presence of excess dodecanol achieved the highest ester yield at the molar ratio of lactic acid to dodecanol of 1:10 (Torres et al., 1999b).Consequently, the excess alcohol achieves the shift of the reaction equilibrium towards the ester formation. In the case of formic acid excess, the ester yield decreases almost $50 \%$ at ratio $2: 1$ and it becomes almost null at ratio 5:1. This result can be due to the enzyme inhibition/denaturation by the high acidity of formic acid or the insufficient quantity of alcohol. For that, new quantity of butan-1-ol was added to the esterification reaction at ratio 5:1 in order to know if the enzyme is still active. New addition of buta-1-nol achieved almost $31 \%$ of ester yield without addition of fresh enzyme. This result confirms that the enzyme is still active and the decrease of ester yield is due to the insufficient quantity of alcohol (data not shown). The 
same result was obtained in previous work between lactic acid and dodecanol. Indeed, it was found that the lower ester yield was obtained with the decrease of dodecanol concentration below $0.05 \mathrm{M}$. This result was due to the decrease in the reaction rate associated with the lower concentration of the reactant (Torres et al., 1999b).

\section{III.1.4. Effect of formic acid concentration}

The maximum concentration of substrates used in the esterification reaction is a challenge to be applied in industrial domain. With the goal of increasing the concentration of formic acid without negative effects on the ester yield or the reaction rate, various concentrations were studied in acetonitrile. The other parameters, such as the formic acid:butan-1-ol molar ratio $1: 3$, the temperature at $50^{\circ} \mathrm{C}, 700 \mathrm{rpm}$ and $2.5 \%(\mathrm{w} / \mathrm{v})$ of Novozym 435 for $24 \mathrm{~h}$, were constant. The results demonstrate that the ester yield is similar up to $0.5 \mathrm{M}$ of formic acid as shown in the Figure 3. At the concentration above $0.5 \mathrm{M}$ of formic acid, the ester yield decreases. This result can be due to the increase of acidity and/or water quantity, related to the formic acid concentration increase, which influences the enzyme activity. To evaluate the potential effect of the acidity, the enzyme was recovered from the reaction medium at the concentration of $1 \mathrm{M}$ of formic acid, washed using hexane in order to remove any water from the support, dried at room temperature during one night and reused in a new reaction (Martins et al., 2013). The results showed that the ester yield was almost null using the reused enzyme at $0.5 \mathrm{M}$ of formic acid (data not shown). This result confirms that the enzyme at the concentration of $1 \mathrm{M}$ of formic acid loses its activity due to the high acidity that denatures the enzyme.

\section{III.1.5. Effect of the lipase charge}

The influence of enzyme loading on the ester yield was studied. Various amounts of Novozym 435 were employed to synthesis of butyl formate in acetonitrile. The other 
parameters, such as the formic acid:butan-1-ol molar ratio 1:3, the concentration of formic acid and butan-1-ol ( $0.5 \mathrm{M}$ and $1.5 \mathrm{M}$ respectively), the temperature at $50^{\circ} \mathrm{C}$ and $700 \mathrm{rpm}$ for $24 \mathrm{~h}$ were constant. The results show that the ester yield increases with increasing amounts of biocatalyst as shown in Figure 4. The best result (almost $90 \%$ of ester yield) is obtained with $20 \mathrm{mg} / \mathrm{ml}$ of Novozym 435, the smallest amount necessary to produce the highest yield of butyl formate. At the amount above $20 \mathrm{mg}$ of Novozym 435, the ester yield does not increase.

\section{III.1.6. Effect of reaction temperature}

To find the optimal temperature of esterification reaction, five levels of temperature (30 to $70{ }^{\circ} \mathrm{C}$ ) were tested. In this experiment, the esterification reaction was carried out in $5 \mathrm{ml}$ of acetonitrile at molar ratio of formic acid and butan-1-ol of 1:3, the concentration of formic acid and butan-1-ol (0.5 M and 1.5 M respectively), 2\% (w/v) of Novozym 435, $700 \mathrm{rpm}$ for 24h. The results show that the optimal esterification temperature is of $40{ }^{\circ} \mathrm{C}$ (Figure 5). At the temperature over $40{ }^{\circ} \mathrm{C}$ to $60{ }^{\circ} \mathrm{C}$, the ester yield is constant due to the high degree of thermal stability of this lipase as reported in literature (Kirk et al., 1992). At $70{ }^{\circ} \mathrm{C}$, the ester yield decreases probably due to the thermal denaturation of lipase. This result is confirmed by other studies that reported the esterification using Novozym 435 at the range of temperatures between 40 and $60^{\circ} \mathrm{C}$ (Martins et al., 2013; Torres et al., 1999a; Torres et al., 2001). Additionally, another study found the optimal temperature at $40^{\circ} \mathrm{C}$ for transesterification catalyzed by Novozym 435 between ethyl formate and octan-1-ol (Janssen et al., 2014).

\section{III.1.7. Effect of shaking speed}

Five speeds of shaking between 300 and $700 \mathrm{rpm}$ were tested for $5 \mathrm{ml}$ of reaction medium. The other parameters such as molar ratio of formic acid: butan-1-ol (1:3), the concentration of formic acid and butan-1-ol (0.5 M and $1.5 \mathrm{M}$ respectively), $2 \%(\mathrm{w} / \mathrm{v})$ of 
Novozym 435 at $40^{\circ} \mathrm{C}$ for $24 \mathrm{~h}$ were held constant. The results show that all shaking speeds

279 resulted in the same ester yield of butyl formate except at shaking speed of 300 rpm (Figure 6). This result confirms that shaking speed at $400 \mathrm{rpm}$ is enough to assure a good contact between the substrates and the lipase.

\section{III.1.8. Effect of molecular sieves}

As hydrolysis is merely the reverse reaction of esterification, the hydration degree of the reaction medium can play an important role in determining the maximal yield of esterification (Aschenbrenner et al., 2009). For that, the presence of various amounts of molecular sieves in the reaction medium in order to control the water quantity was studied. The reaction was realized under the optimal conditions: temperature of $40^{\circ} \mathrm{C}$; formic acid: butan-1-ol molar ratio of 1:3, Novozym 435 content of $2 \%(\mathrm{w} / \mathrm{v})$; acid concentration of $0.5 \mathrm{M}$ and $400 \mathrm{rpm}$ for 24h. In this reaction, there are four sources of water: acetonitrile, formic acid, enzyme support and water generated during esterification reaction. The results show that the addition of various amounts of molecular sieves at the start of reaction has a negative effect on the ester yield in acetonitrile (Figure 7).

Generally, the presence of molecular sieves in reaction medium seems to sequester the generated water and then shift the reaction towards the ester formation. Furthermore, the molecular sieves can also strip the minimal amount of water essential to maintain the enzyme activity and thus decrease the enzyme activity. In general, a low water around the active site of lipase is necessary to maintain the enzyme activity in an esterification system. Therefore, the molecular sieves can play a dual effect: positive effect by the absorption of the generated water in the reaction and negative effect by the absorption of the water necessary for enzyme activity. In the other hand, it can also absorb the polar acids used such as formic or lactic acid due to its small size and its polarity (Torres et al., 1999b). This adsorption phenomenon would 
decrease the concentration of formic acid in the reaction medium and then would decrease its availability for the esterification by lipase.

In our case, the presence of various amounts of molecular sieves decreased the ester yield in acetonitrile due to absorb both the water generated from esterification reaction and necessary water to maintain the enzyme activity. In addition, the molecular sieves can absorb the formic acid in the reaction medium and consequently its availability in reaction medium will be reduced. To confirm this hypothesis, the water content in the reaction medium in the presence and the absence of molecular sieves was determined (Table 3). The water content without molecular sieves is about $1 \%$ corresponding to almost $0.55 \mathrm{M}$ obtained by $0.5 \mathrm{M}$ of formic acid. This water content decreases at $0.1 \%$ in the presence of minimal amount of molecular sieve $(5 \mathrm{mg} / \mathrm{ml})$. The low water amount decreases the conversion of formic acid at a rate of $20 \%$ probably due to insufficient quantity of water to maintain the enzyme activity. In previous work, the esterification between lactic acid $(0.55 \mathrm{M})$ and dodecanol $(0.55 \mathrm{M})$ resulted in $1.3 \%$ of generated water (almost $0.7 \mathrm{M}$ ) (Torres et al., 1999b). In the same work, it was found that $0.28 \%$ of water in reaction medium is necessary to maintain the enzyme activity and to realize maximal conversion of lactic or glycolic acid. This result confirms why the presence of $5 \mathrm{mg}$ of molecular sieve in our reaction medium decreased the ester yield.

\section{III.1.9. Effect of alcohol chain length}

Esterification of formic acid was carried out using two alcohols (butan-1-ol and octan-1ol) under the same optimal conditions described above. The optimal conditions determined were acetonitrile as reaction medium, temperature of $40^{\circ} \mathrm{C}$, molar ratio of $1: 3$ (formic acid: alcohol); Novozym 435 content of $2 \%$ (w/v), acid concentration of $0.5 \mathrm{M}$. The results show that the same maximum yield of ester (almost 93\%) is obtained for $8 \mathrm{~h}$ in the presence of butan-1-ol with initial reaction rate of $0.048 \mathrm{M} / \mathrm{h}$ (Figure 8 -A) and for $7 \mathrm{~h}$ in the presence of octan-1-ol with initial reaction rate of $0.06 \mathrm{M} / \mathrm{h}$ (Figure $8-\mathrm{B}$ ). So, the reaction rate in the 
presence of octan-1-ol was higher than that in the presence of butan-1-ol. In previous studies, it was found that the esterification of lactic acid with alcohols constituted by 8, 12 and 16 carbons achieved the same ester yield (94-96\%) for 24-48h using Novozym 435 (Roenne et al., 2005; Torres et al., 1999b) without specifying the time required to obtain the maximum yield for each alcohol. These results confirm that Novozym 435 has a higher affinity towards the alcohol with long chains than short chains (Roenne et al., 2005).

Kinetic parameters of Michaelis-Menten ( $K m$ and $\operatorname{Vmax}$ ) were determined by a Lineweaver-Burk plot. The results demonstrate that $\mathrm{Km}$ with octan-1-ol $(0.38 \pm 0.01 \mathrm{M})$ is lower than that for butan-1-ol $(0.48 \pm 0.02 \mathrm{M})$ while the maximum velocity Vmax of reaction with octan-1-ol $(0.0026 \pm 0.0004 \mathrm{M} / \mathrm{min})$ is almost 2 fold higher than that with butan-1-ol $(0.0011 \pm 0.0003 \mathrm{M} / \mathrm{min})$. Consequently, the catalytic efficiency $(\operatorname{Vmax} / \mathrm{Km})$ with octan-1-ol $(0.0071 \pm 0.002)$ is almost 3 -fold higher than that with butan-1-ol $(0.0022 \pm 0.001)$. As the $K m$ value reflects the affinity between the enzyme and substrate, the lower value with octan1-ol indicates a higher affinity of Novozym 435 for esterification of formic acid with octan-1ol.

\section{III.2. Esterification reaction in solvent-free system}

Due to the growing safety and environmental concerns as well as to reduce the toxicity of products obtained by the reaction, the elimination of solvent in esterification reaction is desirable. In this case, the alcohol is considered as a reaction medium and a nucleophile reagent (acyl acceptor) in the same time.

Initially, the esterification reaction of formic acid was performed under the same optimal conditions described above in the presence of solvent except the formic acid:alcohol molar ratio and the acid concentration. In this study, butan-1-ol is used as a reaction medium at $10 \mathrm{M}$ and various concentrations of formic acid were studied. The results demonstrate that 
the ester yield is similar up to $1 \mathrm{M}$ of formic acid as shown in the Figure 9. At the concentration of formic acid above $1 \mathrm{M}$, the ester yield decreases probably due to the negative effect of acidity on the enzyme activity. Consequently, the acid:alcohol molar ratio of 1:10 was desirable for esterification reaction of formic acid in the presence of butan-1-ol in solvent-free system.

In order to study the effect of alcohol chain length on the ester yield, the esterification reaction was carried out without organic solvent using two alcohols (butan-1-ol C4 and octan1-ol C8) under previous optimal conditions. The results showed that almost $90 \%$ of ester yield was obtained after $5 \mathrm{~h}$ with butan-1-ol and after $3 \mathrm{~h}$ with octan-1-ol as shown in figure 10 . This result is in accordance with the result obtained in the case of esterification reaction of formic acid with butan-1-ol and octan-1-ol in acetonitrile used as a reaction medium. Despite the octan-1-ol is a fatty acid alcohol and its viscosity is higher than that of butan-1-ol, the reaction rate of esterification in octan-1-ol used as a reaction medium was higher than that in butan-1ol. This result confirms that shacking speed was enough in order to distribute the formic acid in reaction medium.

Kinetic parameters of Michaelis-Menten ( $\mathrm{Km}$ and Vmax) were determined by a Lineweaver-Burk plot to confirm the difference between esterification reaction rates of formic acid in butan-1-ol and octan-1-ol as reaction media. The results demonstrated that the constant $(\mathrm{Km})$ of esterification reaction in octan-1-ol $(0.18 \pm 0.01 \mathrm{M})$ was lower than that of esterification reaction in butan-1-ol $(0.23 \pm 0.02 \mathrm{M})$ while the maximum velocity (Vmax) of reaction in octan-1-ol $(0.0082 \pm 0.0003 \mathrm{M} / \mathrm{min})$ was almost 2 fold higher than that of reaction in butan-1-ol $(0.0045 \pm 0.0003 \mathrm{M} / \mathrm{min})$. Consequently, the substrate specificity $(\mathrm{Vmax} / \mathrm{Km})$ of reaction in octan-1-ol $(0.0455 \pm 0.0005)$ was almost two-fold higher than that of reaction in butan-1-ol (0.0216 \pm 0.0003$)$. Consequently, the catalytic efficiency for esterification reaction of formic acid in octan-1-ol is higher than that in butan-1-ol due to a better $\mathrm{Km}$. 


\section{III.3. Lipase stability and re-use}

One of important properties of immobilized enzymes is the possibility of their recovery and reusability. These properties give important economic and environmental advantages in future industrial applications using immobilized enzymes. For that, the possibility of recovery and reusability of Novozym 435 was tested. The esterification reaction was performed in solvent-free system under optimal conditions described above: formic acid (1 M), octan-1-ol (10 M), temperature of $40^{\circ} \mathrm{C}$; formic acid:octan-1-ol molar ratio of $1: 10$, enzyme content of $2 \%(\mathrm{w} / \mathrm{v})$ and $400 \mathrm{rpm}$ for $4 \mathrm{~h}$. Then, lipase enzyme was recovered, washed with n-hexane, dried during one night at room temperature and then reused in a new fresh reaction. The washing process is repeated between batches and one batch is realized each four days for one month. A control was carried out without washing with n-hexane. The results are expressed as enzyme activity remained from washed enzyme compared with the enzyme activity of fresh enzyme.

The results indicate that the reused enzyme with treatment (washing with n-hexane) keeps almost $97 \%$ of its initial activity for 6 reaction batches for twenty days. In contrast, the reused enzyme without any treatment loses about $60 \%$ of its initial activity after six reaction batches for twenty days. In previous study, $70 \%$ of original activity of Novozym 435 were recovered for 14 reaction batches of esterification of acetic acid with butan-1-ol, while its original activity was zeroed in the third batch without washing in hexane (Martins et al., 2013). In fact, the washing process with n-hexane after each reaction batch is a necessary process to recover the initial enzyme activity due to the accumulation of acid and water in the site active of enzyme (Martins et al., 2013).

\section{Conclusion}


The present article studied the feasibility of the direct esterification of formic acid with straight-chain alcohols (butan-1-ol and octan-1-ol) using the commercial immobilized lipase B from Candida antarctica (Novozym 435) as biocatalyst in acetonitrile and in solvent-free system. In solvent system, the optimal conditions are: $0.5 \mathrm{M}$ of formic acid, $1.5 \mathrm{M}$ of alcohol resulting in formic acid/alcohol molar ratio of $1: 3,2 \%$ of Novozym 435 at $40^{\circ} \mathrm{C}$ and $400 \mathrm{rpm}$ in acetonitrile solvent without molecular sieves. In solvent-free system, the esterification reaction was performed under the same conditions than in solvent system except the acid concentration of $1 \mathrm{M}$ and alcohol used as a nucleophile (acyl acceptor) and a reaction medium at $10 \mathrm{M}$ in the same time resulting in molar ratio of 1:10. All esterification reactions resulted in the same ester yield (almost 90\%) with the difference in required reaction time to realize that yield. Among all esterification reactions, those with octan-1-ol in solvent-free system is the better regarding the quantity of esterified formic acid, catalytic efficiency of lipase and the reaction time required to realize the maximum ester yield. Additionally, under the optimal conditions, the immobilized lipase can be reused keeping almost $97 \%$ of its initial activity after treatment process (washing with n-hexane) for six reaction batches.

In conclusion, the fact that enzymatic esterification of formic acid with different alcohols in solvent-free systems is feasible is very promising for food and cosmetic applications of formate esters.

\section{Acknowledgments}

This work was performed, in partnership with the SAS PIVERT, within the frame of the French Institute for the Energy Transition (Institut pour la Transition Energétique (ITE) P.I.V.E.R.T. (www.institut-pivert.com) selected as an Investment for the Future ("Investissements d'Avenir"). This work was supported, as part of the Investments for the Future, by the French Government under the reference ANR-001-01. The authors want also to thank Ministère de l'Enseignement Supérieur et de la Recherche, Région Hauts-de-France 
(CPER ALIBIOTECH) and REALCAT platform ('Future Investments' program (PIA), with the contractual reference 'ANR-11-EQPX-0037') for supporting this work.

\section{References}

Almeida, S., de Meneses, A. C., de Araujo, P. H. H., \& de Oliveira, D., 2007. A review on enzymatic synthesis of aromatic esters used as flavor ingredients for food, cosmetics and pharmaceuticals industries. Trends Food Sci.Technol. 69, 95-105.

Aschenbrenner, E. M., Weiss, C. K., \& Landfester, K., 2009. Enzymatic Esterification in Aqueous Miniemulsions. Chem.Eur. J. 15, 2434-2444.

Bornscheuer, U. T., 2002. Microbial carboxyl esterases: classification, properties and application in biocatalysis. Fems Microbiol. Rev. 26, 73-81.

de Barros, D. P. C., Fonseca, L. P., Fernandes, P., Cabral, J. M. S., \& Mojovic, L., 2009. Biosynthesis of ethyl caproate and other short ethyl esters catalyzed by cutinase in organic solvent. J. Mol. Catal. B-Enzym. 60, 178-185.

Ferroni, F. M., Tolmie, C., Smit, M. S., \& Opperman, D. J., 2017. Alkyl Formate Ester Synthesis by a Fungal Baeyer-Villiger Monooxygenase. Chembiochem, 18, 515-517.

Frohlich, P., Albert, K., \& Bertau, M., 2011. Formate dehydrogenase - a biocatalyst with novel applications in organic chemistry. Org. Biomol. Chem. 9, 7941-7950.

Gunstone, F. D., 1999. Enzymes as biocatalysts in the modification of natural lipids. J. Sci. Food Agric. 79, 1535-1549. 
Janssen, L. M. G., van Oosten, R., Paul, C. E., Arends, I., \& Hollmann, F., 2014. Lipasecatalyzed transesterification of ethyl formate to octyl formate. J. Mol. Catal. B-Enzym. $105,7-10$.

Khan, N. R., \& Rathod, V. K., 2015. Enzyme catalyzed synthesis of cosmetic esters and its intensification: A review. Process Biochem. 50, 1793-1806.

Kiran, K. R., Manohar, B., Karanth, N. G., \& Divakar, S., 2000. Response surface methodological study of esterification of lactic acid with palmitic acid catalyzed by immobilized lipases from Mucor miehei and porcine pancreas. Eur. Food Res. Technol. $211,130-135$.

Kirk, O., Björkling, F., Sven, E., \& Larsen, T. O., 1992. Fatty acid specificity in lipase catalyzed synthesis of glucoside esters. Biocatal. Biotransformation 6, 127-134.

Kremnicky, L., Mastihuba, V., \& Cote, G. L., 2004. Trichoderma reesei acetyl esterase catalyzes transesterification in water. J. Mol. Catal. B-Enzym. 30, 229-239.

Lineweaver, H., \& Burk, D., 1934. The determination of enzyme dissociation constants. J. Am. Chem. Soc. 56, 658-666.

Martins, A. B., Schein, M. F., Friedrich, J. L. R., Fernandez-Lafuente, R., Ayub, M. A. Z., \& Rodrigues, R. C., 2013. Ultrasound-assisted butyl acetate synthesis catalyzed by Novozym 435: Enhanced activity and operational stability. Ultrason. Sonochem. 20, 1155-1160.

Mirzarakhmetova, D. T., 2012. Enzymatic Esterification of Carboxylic Acids and Higher Alcohols in Organic Medium. Inter. J. Chem. Mol. Nucl. Mat. Metal. Eng. 6, 1-3. 
Nurdock, G. A., 2010. Flavors ingredients. Taylor \& Francis Group.

465

466

467

Park, D. W., Kim, J. S., Haam, S., Kim, H. S., \& Kim, W. S., 2001. Lipase-catalyzed synthesis of beta-methylglucoside esters containing an alpha-hydroxy acid. Biotechnol. Lett. 23, 1947-1952.

Riemenschneider, W., \& Bolt, H. M., 2005. "Esters, Organic" Ullmann's Encyclopedia of Industrial Chemistry. Weinheim: Wiley-VCH.

Roenne, T. H., Xu, X. B., \& Tan, T. W., 2005. Lipase-catalyzed esterification of lactic acid with straight-chain alcohols. J. A. Oil Chem. Soc. 82, 881-885.

Skrzynska, E., Ftouni, J., Girardon, J. S., Capron, M., Jalowiecki-Duhamel, L., Paul, J. F., \& Dumeignil, F., 2016a. Quasi-Homogeneous Oxidation of Glycerol by Unsupported Gold Nanoparticles in the Liquid Phase. Chemsuschem, 5, 2065-2078.

Skrzynska, E., Zaid, S., Addad, A., Girardon, J. S., Capron, M., \& Dumeignil, F., 2016 b. Performance of $\mathrm{Ag} / \mathrm{Al} 2 \mathrm{O} 3$ catalysts in the liquid phase oxidation of glycerol - effect of preparation method and reaction conditions. Catal. Sci. Technol. 6, 3182-3196.

Sundell, R., \& Kanerva, L. T., 2014. Lipases in the Regioselective Preparation of Glyceric Acid Esters of Methyl Glycosides. Euro. J. Org. Chem. 22, 4971-4978.

Torres, C., Bernabe, M., \& Otero, C., 1999a. Part II. Two enzymatic procedures for the selective synthesis of malic acid monoesters. Enzym. Microb. Technol. 25, 753-761.

Torres, C., \& Otero, C., 1999b. Part I. Enzymatic synthesis of lactate and glycolate esters of fatty alcohols. Enzym. Microb. Technol. 25, 745-752. 
484 Torres, C., \& Otero, C., 2001. Part III. Direct enzymatic esterification of lactic acid with fatty $485 \quad$ acids. Enzym. Microb. Technol. 29, 3-12.

486

487

488 
490

491

492

493

494

495

496

497

498

499

500

501

502

503

504

505

506

507

508

509

510

511

Table 1: Hydrolytic activity of different lipases

Table 2: Ester yield of butyl formate catalyzed by different lipases

Table 3: Water content of reaction medium in the presence of various amounts of molecular sieves

\section{Figure Captions}

Fig. 1: Ester yield (butyl formate) in various solvents. Reaction conditions: formic acid (0.2 M), butanol (0.2 M), Novozym $435(2.5 \%(\mathrm{w} / \mathrm{v}))$ and $5 \mathrm{ml}$ of organic solvent, $24 \mathrm{~h}, 700 \mathrm{rpm}$ and $50^{\circ} \mathrm{C}$. Each value is expressed as mean \pm standard deviation $(\mathrm{n}=3)$. Values not followed by the same letter in each line are significantly different at the $0.05 \%$ level (Duncan's test).

Fig. 2: Effect of the formic acid/butan-1-ol molar ratio in the enzymatic synthesis of butyl formate. Reaction conditions: 0.1 $\mathrm{M}$ of formic acid and 0.1 $\mathrm{M}$ of butan-1-ol (molar ratio 1:1), $2.5 \%$ (w/v) Novozym 435, $5 \mathrm{ml}$ acetonitrile, $24 \mathrm{~h}, 50^{\circ} \mathrm{C}$ and $700 \mathrm{rpm}$. Each value is expressed as mean \pm standard deviation $(n=3)$. Values not followed by the same letter in each line are significantly different at the $0.05 \%$ level (Duncan's test).

Fig. 3: Effect of formic acid concentrations on the enzymatic synthesis of butyl formate in acetonitrile. Conditions: formic acid/butan-1-ol molar ratio 1:3, 2.5\% (w/v) Novozym 435, $24 \mathrm{~h}, 50^{\circ} \mathrm{C}, 700 \mathrm{rpm}$ were constant. Each value is expressed as mean \pm standard deviation $(\mathrm{n}=$ 3). Values not followed by the same letter in each line are significantly different at the $0.05 \%$ level (Duncan's test).

Fig. 4: Effect of the amount of Novozym 435 on the enzymatic synthesis of butyl formate ester. Conditions: $0.5 \mathrm{M}$ of formic acid, $1.5 \mathrm{M}$ of butan-1-ol, $5 \mathrm{ml}$ of acetonitrile, $50^{\circ} \mathrm{C}$ and 
$700 \mathrm{rpm}$. Each value is expressed as mean \pm standard deviation $(\mathrm{n}=3)$. Values not followed by the same letter in each line are significantly different at the $0.05 \%$ level (Duncan's test).

Fig. 5: Effect of reaction temperature on the synthesis of butyl formate obtained using Novozym 435 lipase. Reaction conditions: $0.5 \mathrm{M}$ of formic acid; $1.5 \mathrm{M}$ of butan-1-ol; 2\% (w/v) of Novozym 435; $24 \mathrm{~h}$; and $700 \mathrm{rpm}$ in $5 \mathrm{ml}$ of acetonitrile. Each value is expressed as mean \pm standard deviation $(n=3)$. Values not followed by the same letter in each line are significantly different at the $0.05 \%$ level (Duncan's test).

Fig. 6: Effect of shaking speed on the synthesis of butyl formate ester. Reaction conditions: $0.5 \mathrm{M}$ of formic acid; $1.5 \mathrm{M}$ of butan-1-ol; $2 \%(\mathrm{w} / \mathrm{v})$ of Novozym 435 for $24 \mathrm{~h}$ in $5 \mathrm{ml}$ of acetonitrile. Each value is expressed as mean \pm standard deviation $(n=3)$. Values not followed by the same letter in each line are significantly different at the $0.05 \%$ level (Duncan's test).

Fig. 7: Effect of the presence of molecular sieves in reaction medium on the yield of butyl formate. Conditions: formic acid : butan-1-ol molar ratio of 1:3, 0.5 $\mathrm{M}$ of formic acid, $1.5 \mathrm{M}$ of butan-1-ol in acetonitrile solvent at $40^{\circ} \mathrm{C}, 400 \mathrm{rpm}$ for $24 \mathrm{~h}$. Each value is expressed as mean \pm standard deviation $(n=3)$. Values not followed by the same letter in each line are significantly different at the $0.05 \%$ level (Duncan's test).

Fig. 8: Effect of alcohol chain length on ester yield. Reaction conditions: $0.5 \mathrm{M}$ of formic acid; 1.5 M of alcohol (butan-1-ol) (A) and (octan-1-ol) (B); formic acid : alcohol molar ratio $(1: 3) ; 2 \%(\mathrm{w} / \mathrm{v})$ Novozym $435 ; 40^{\circ} \mathrm{C}$; and $400 \mathrm{rpm}$ in acetonitrile solvent. Each value is expressed as mean \pm standard deviation $(n=3)$. Values not followed by the same letter in each line are significantly different at the $0.05 \%$ level (Duncan's test). 
534 Fig. 9: Effect of formic acid concentration on the enzymatic synthesis of butyl formate in 535 solvent-free system. Conditions: $10 \mathrm{M}$ of butan-1-ol, $2 \%(\mathrm{w} / \mathrm{v})$ of Novozym 435 at $40^{\circ} \mathrm{C}$ and $536400 \mathrm{rpm}$ for $24 \mathrm{~h}$ were held constant. Each value is expressed as mean \pm standard deviation (n

$537=3$ ). Values not followed by the same letter in each line are significantly different at the $538 \quad 0.05 \%$ level (Duncan's test).

539 Fig. 10: Effect of chain length of alcohols used as a reaction medium on ester yield. Optimal 540 conditions: $1 \mathrm{M}$ of formic acid; $10 \mathrm{M}$ of alcohol (butan-1-ol, C4) (A) and (octan-1-ol, C8) 541 (B); substrate molar ratio $(1: 10) ; 2 \%(\mathrm{w} / \mathrm{v})$ Novozym $435 ; 40^{\circ} \mathrm{C}$; and $400 \mathrm{rpm}$. Value is 542 expressed as mean \pm standard deviation $(n=3)$. Values not followed by the same letter in 543 each line are significantly different at the $0.05 \%$ level (Duncan's test).

544 Fig. 11: Retained initial activity of Novozym 435 with treatment (A) (washing with n-hexane) 545 and without any treatment (B). All reactions were carried out at the optimal conditions: formic 546 acid $(1 \mathrm{M})$; octan-1-ol $(10 \mathrm{M})$; temperature of $40^{\circ} \mathrm{C}$; formic acid/octan-1-ol molar ratio of $547 \quad 1: 10$, enzyme content of $2 \%(\mathrm{w} / \mathrm{v})$ and $400 \mathrm{rpm}$ for $4 \mathrm{~h}$. 
Fig. 1

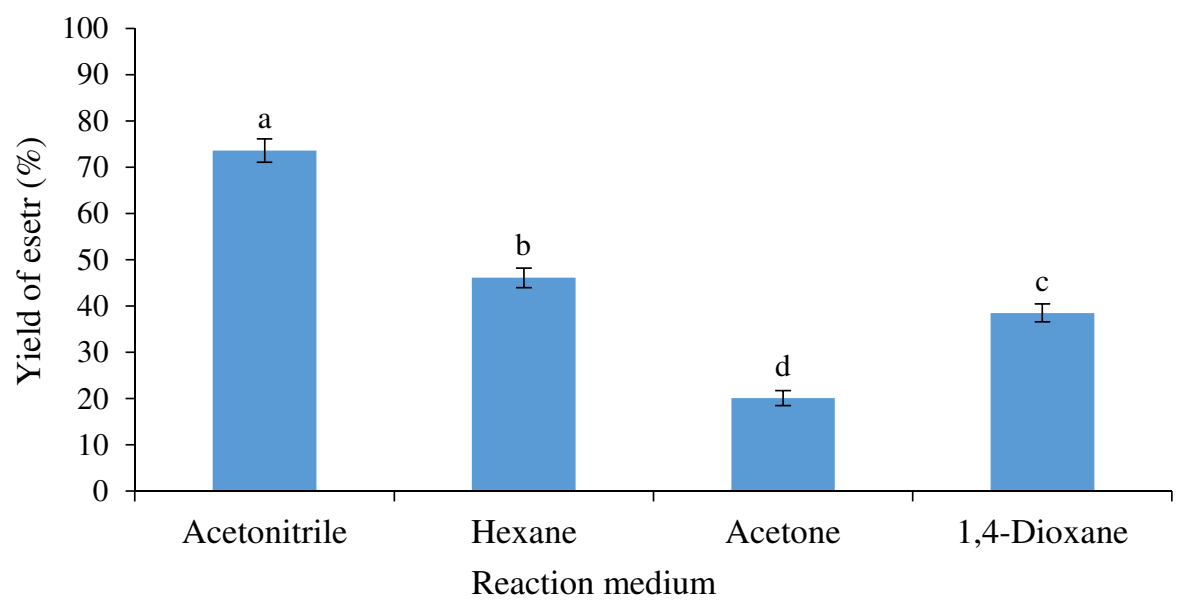


Fig.2

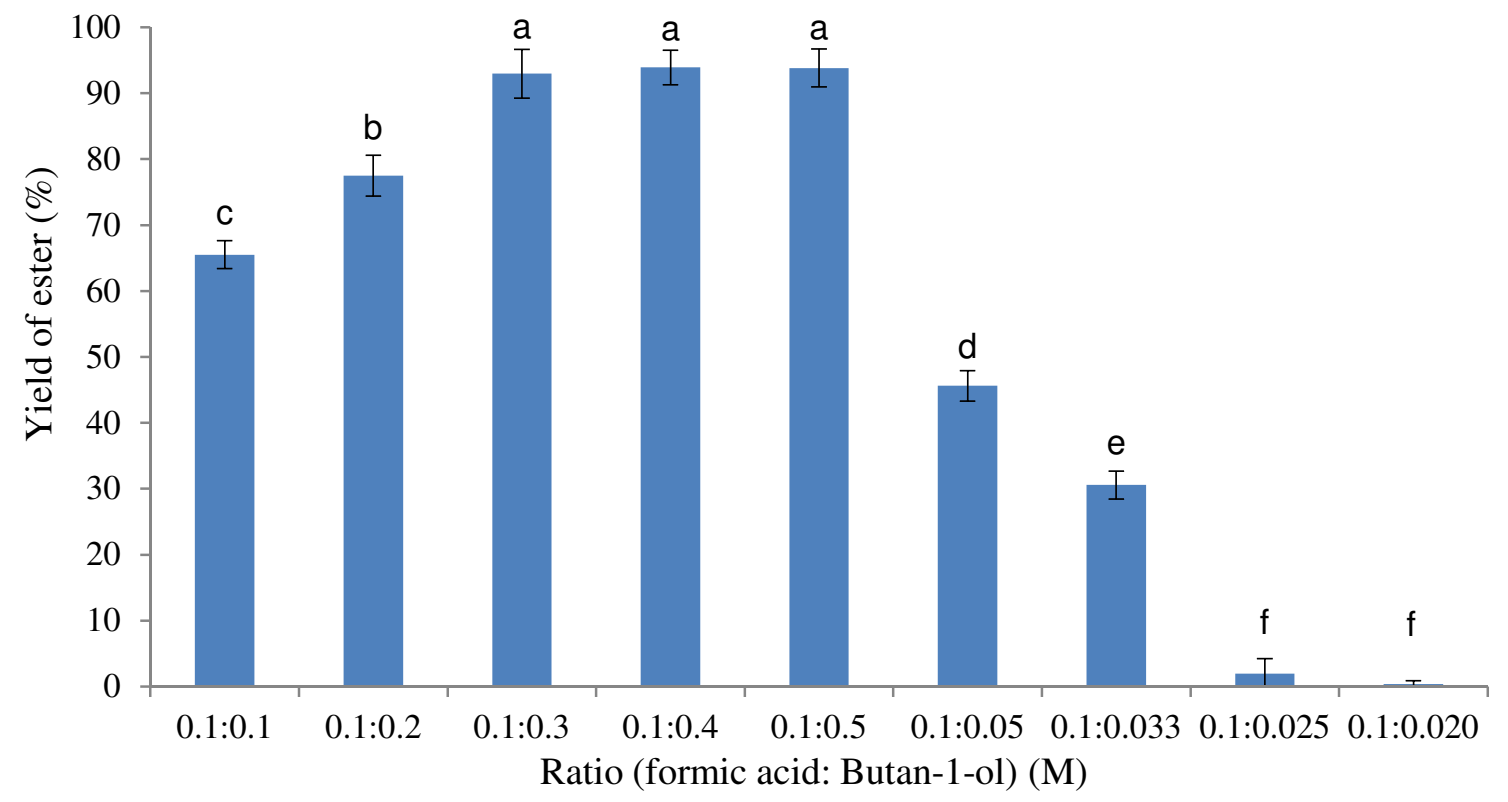


Fig. 3

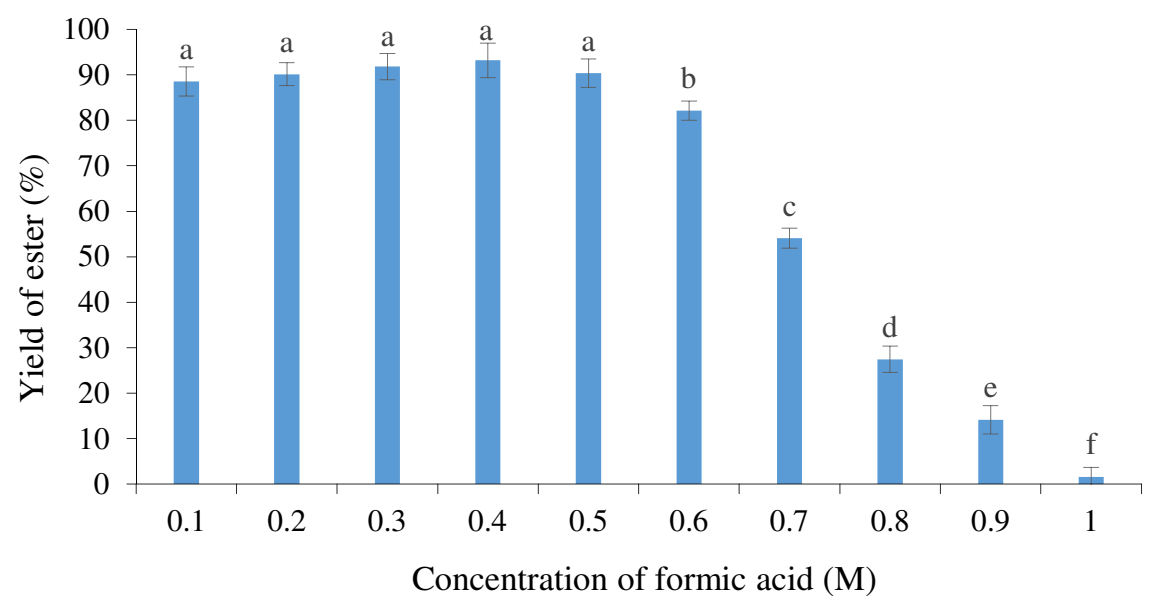


Fig. 4

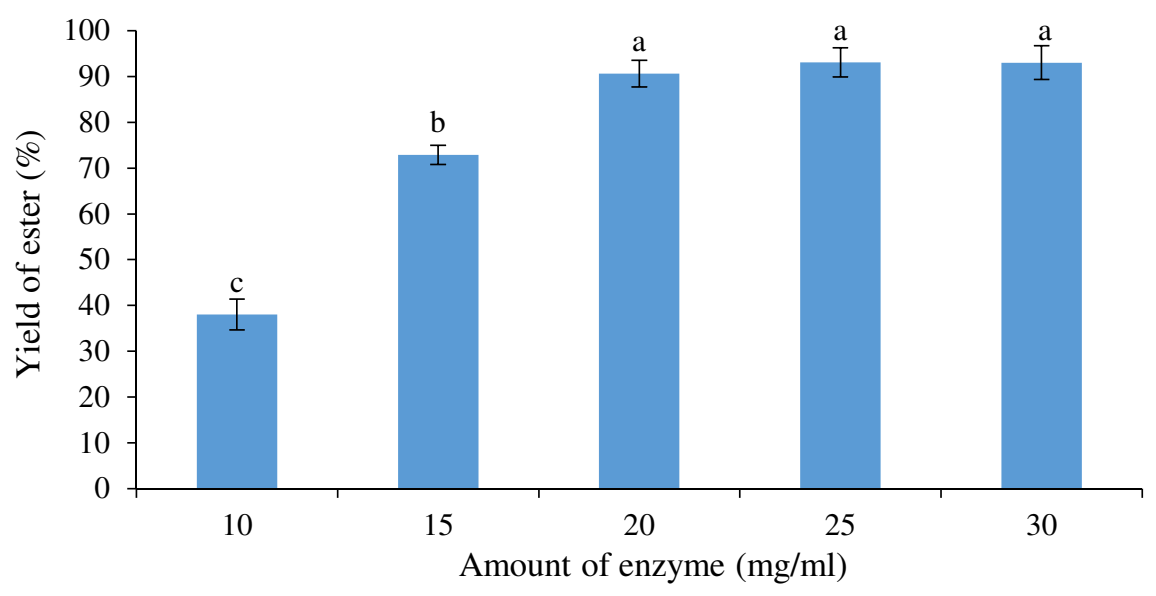


Fig. 5

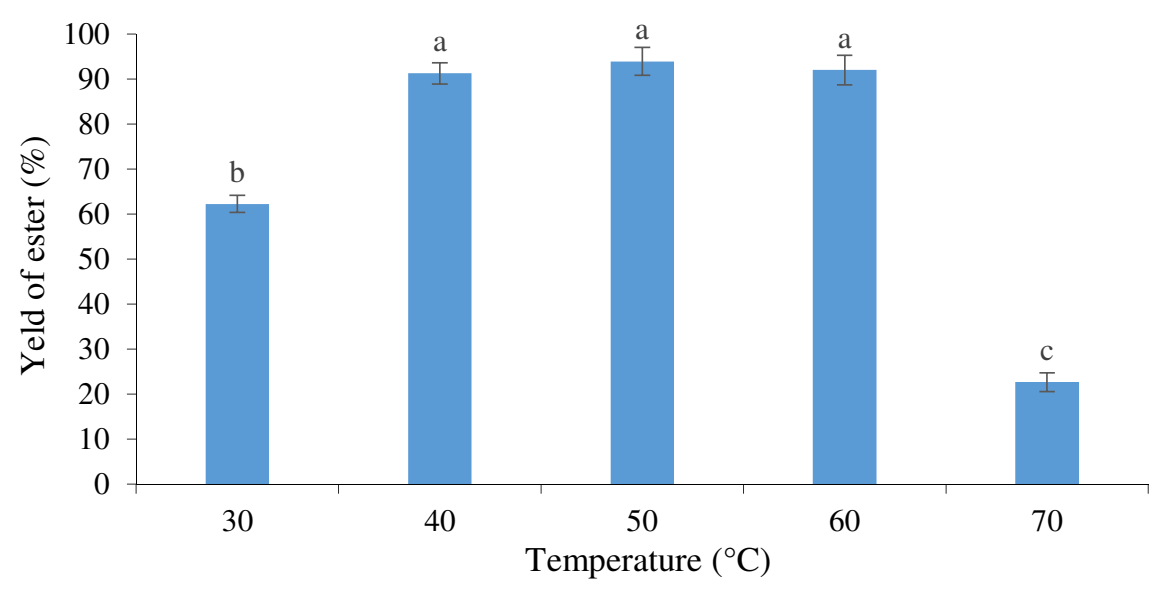


Fig. 6

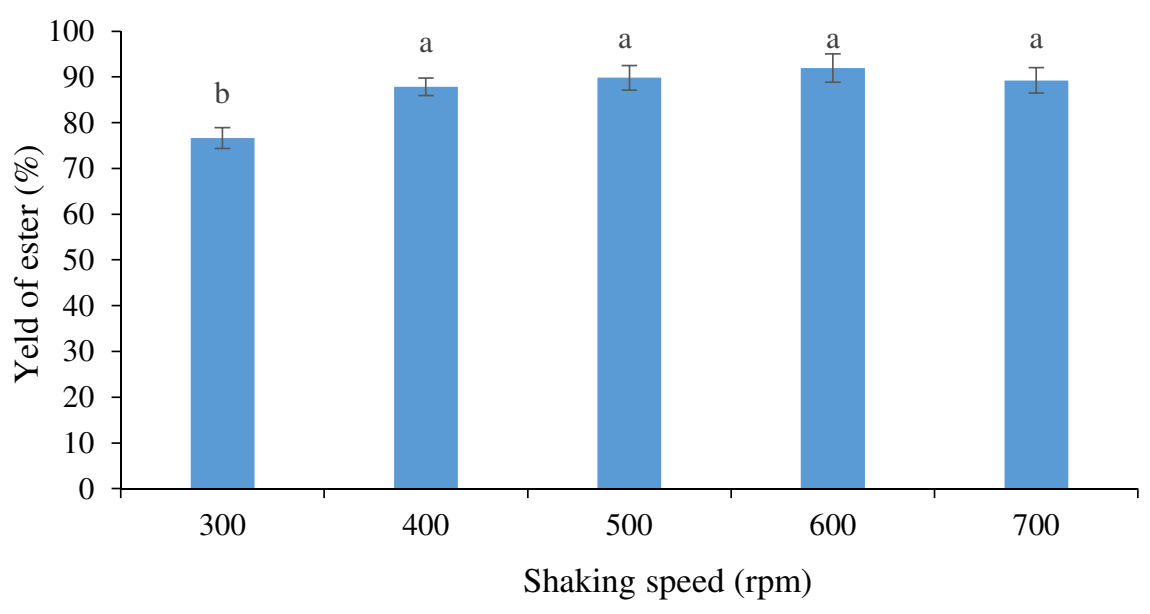


Fig. 7

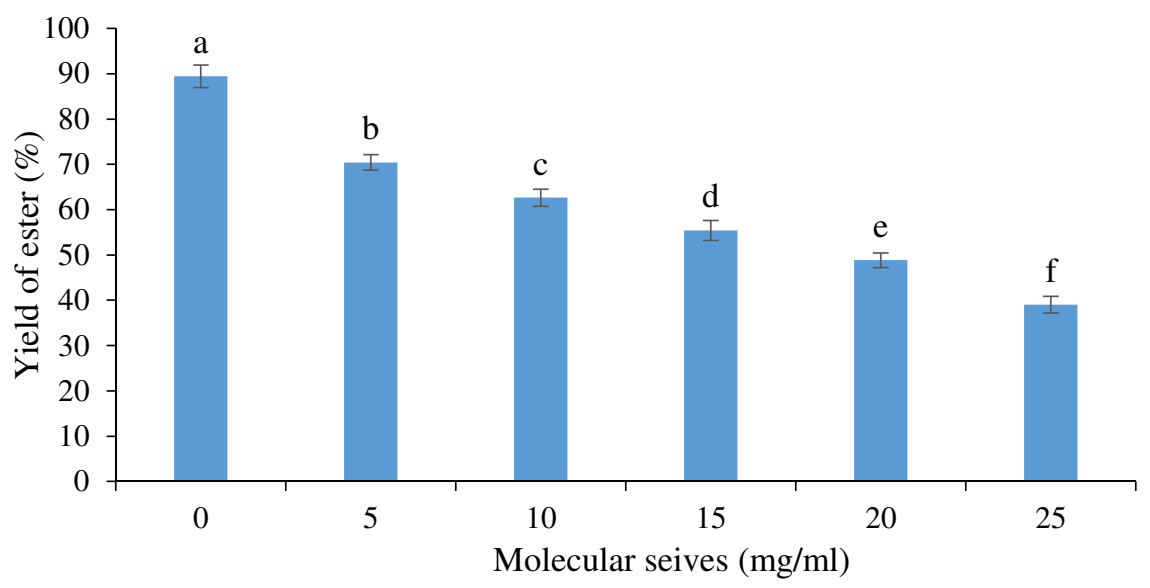


Fig. 8
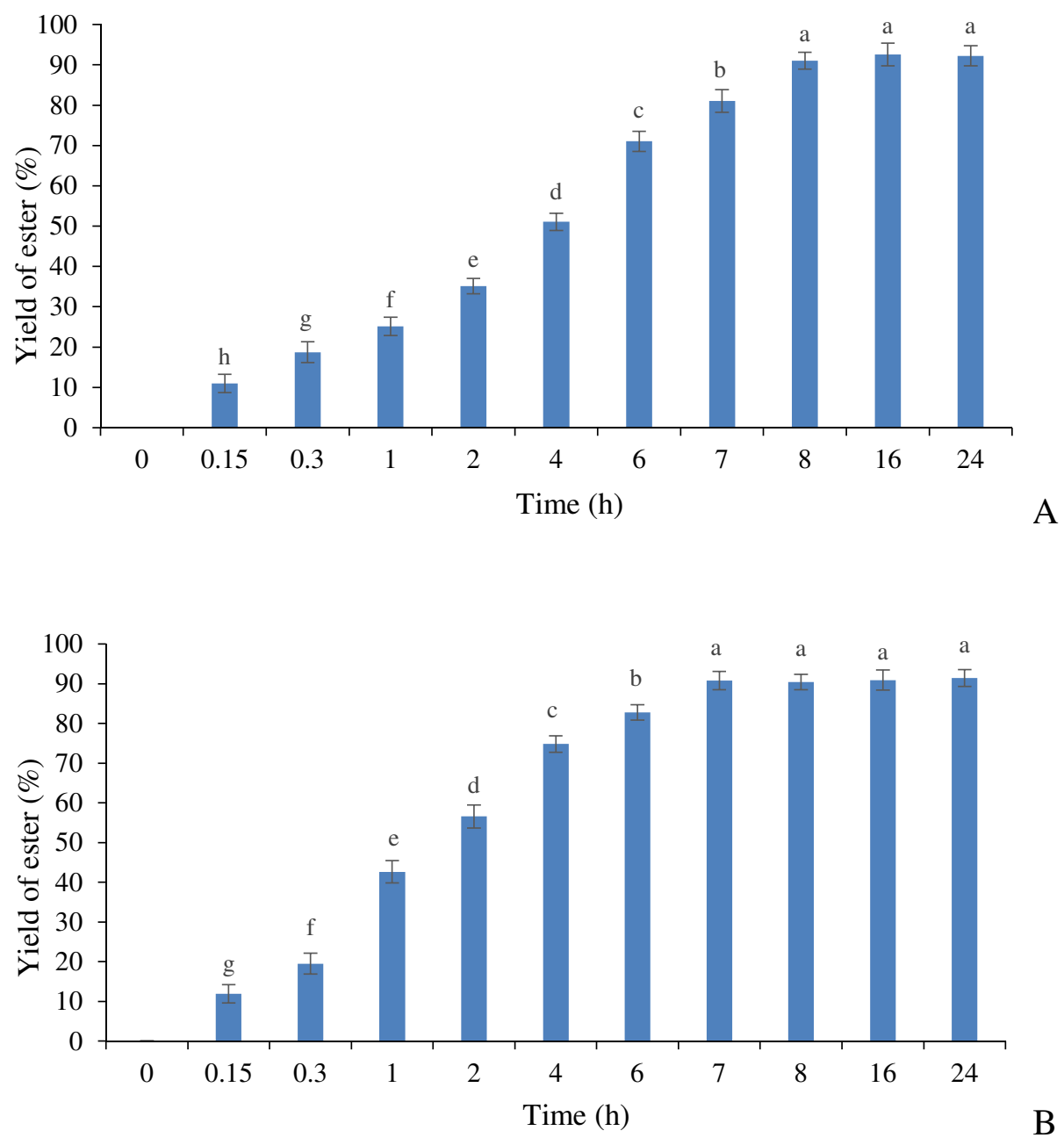
Fig. 9

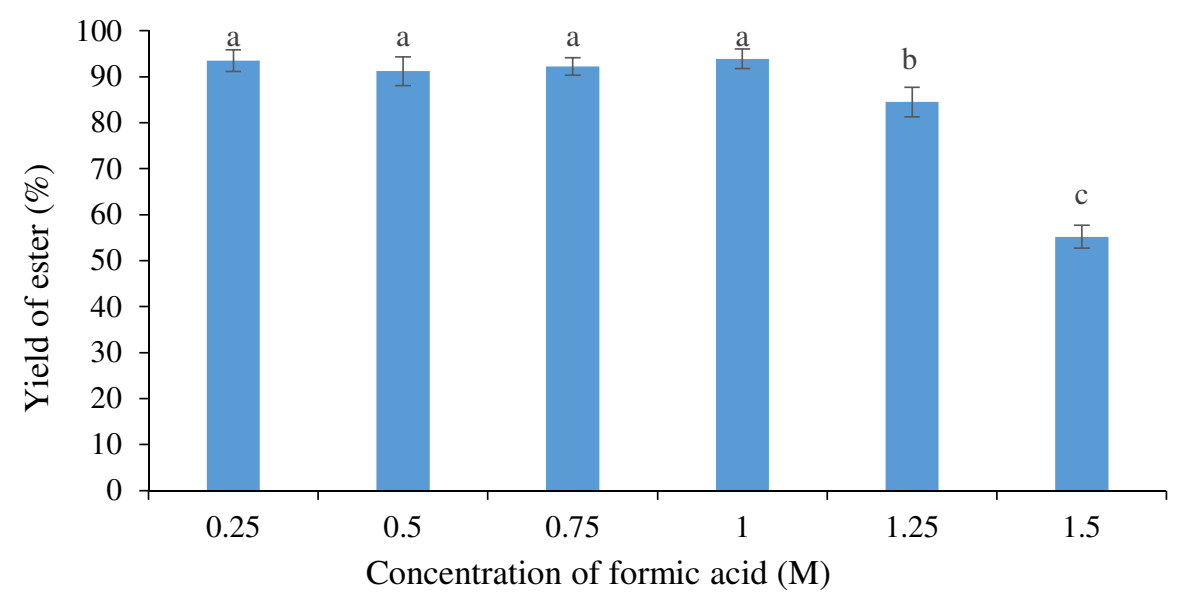


Fig. 10
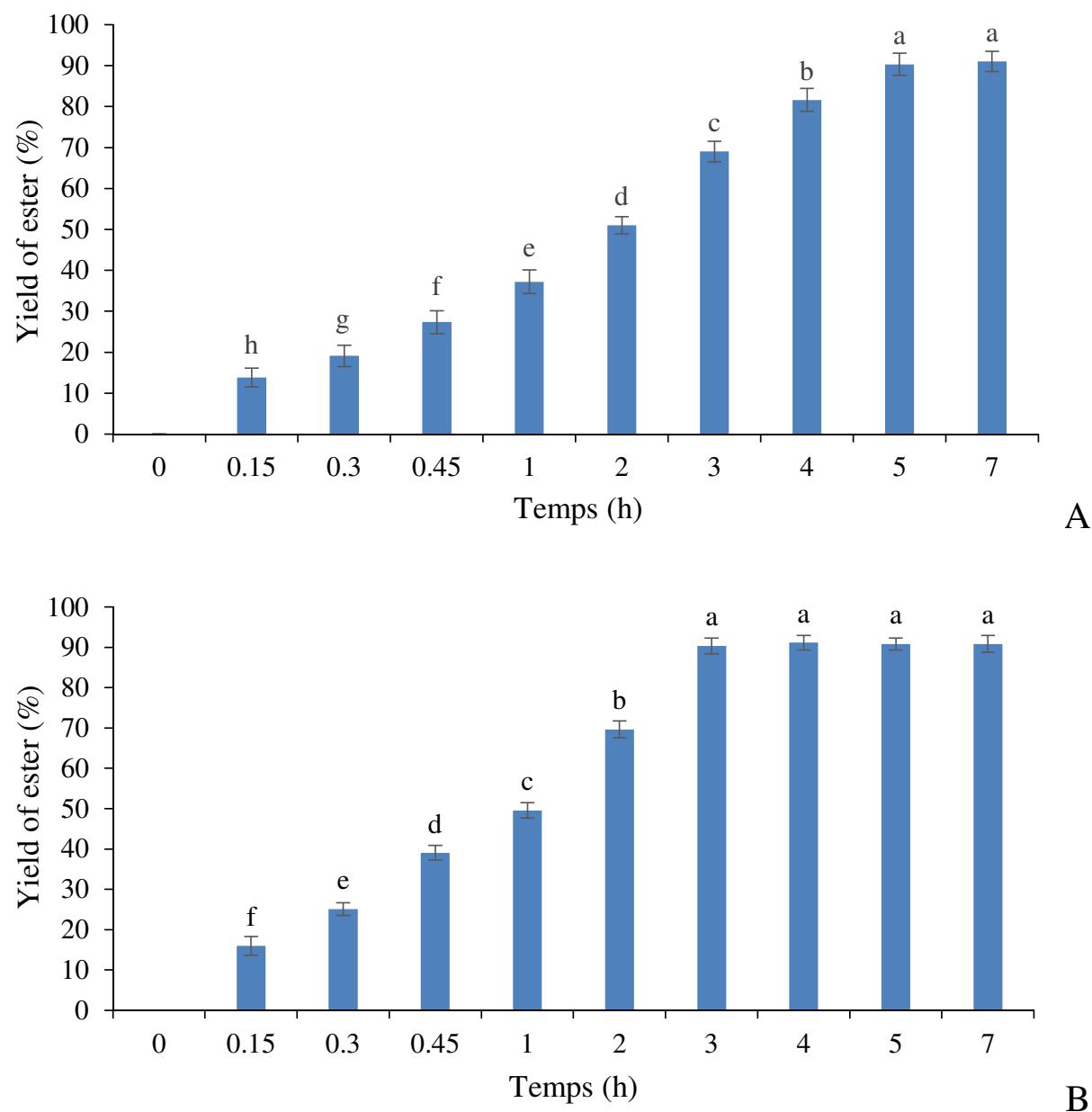
Fig. 11
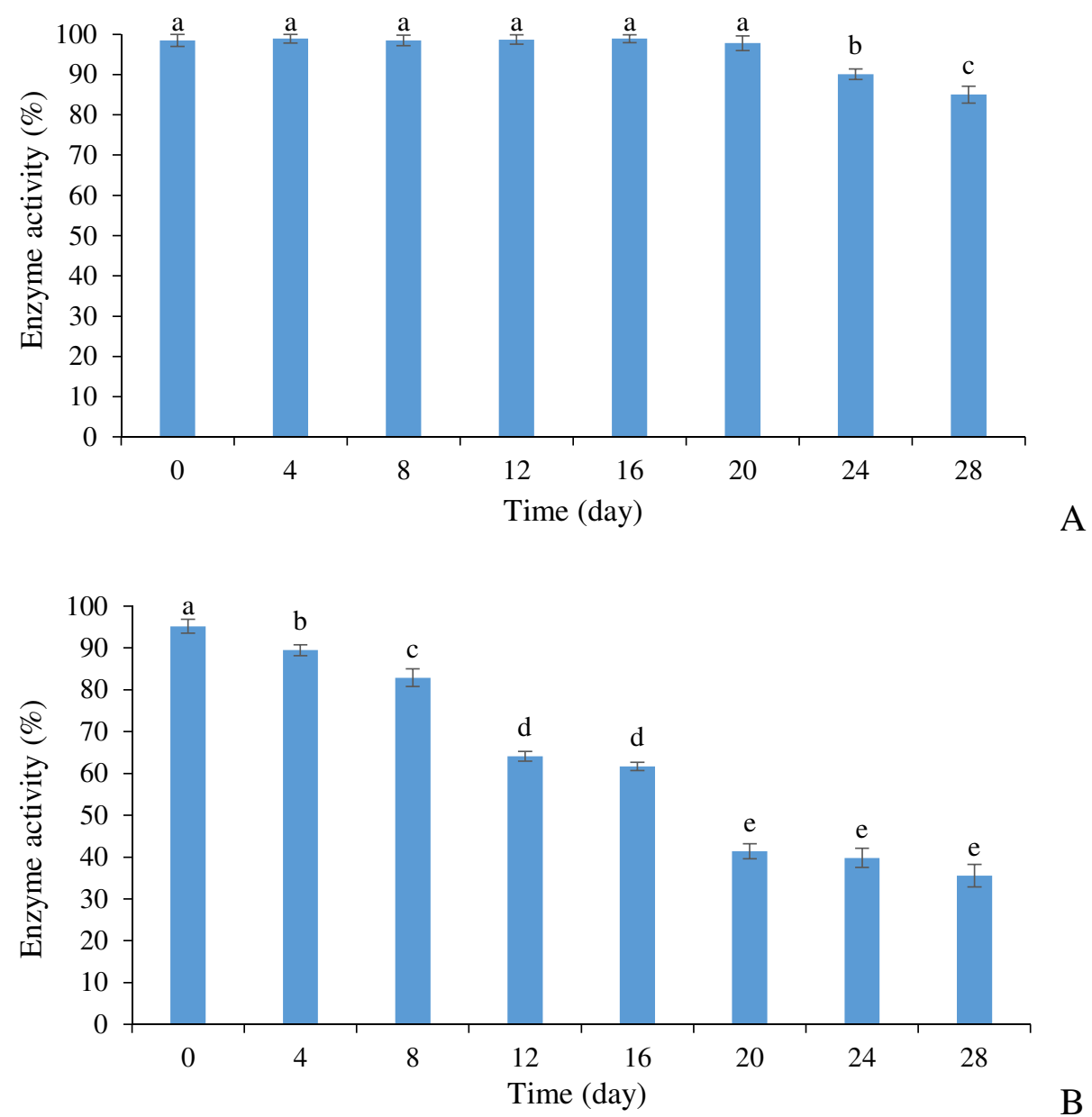
Table 1: Hydrolytic activity of different lipases

\begin{tabular}{l|c}
\hline \multicolumn{1}{c|}{ Immobilized lipase } & Hydrolytic activity (U/mg) \\
\hline L. Candida rugosa & $1.2 \pm 0.05^{\mathrm{b}}$ \\
\hline L. Candida antarctica & $1.1 \pm 0.15^{\mathrm{bc}}$ \\
\hline L. Candida antarctica $(\mathrm{CalB})$ & $1.2 \pm 0.05^{\mathrm{b}}$ \\
\hline Novozym 435, Candida antarctica & $0.9 \pm 0.10^{\mathrm{cd}}$ \\
\hline Novolime & $1.3 \pm 0.15^{\mathrm{ab}}$ \\
\hline Lipozym TL IM, Thermomyces lanuginosus & $1.4 \pm 0.10^{\mathrm{a}}$ \\
\hline Lipozym RM IM, Rhizomucor meihei & $1.1 \pm 0.05^{\mathrm{b}}$ \\
\hline \multicolumn{1}{c}{ Free lipase } & Hydrolytic activity $(\mathrm{U} / \mu \mathrm{l})$ \\
\hline Lipozym TL, Mucor meihei & $6.9 \pm 0.25^{\mathrm{ab}}$ \\
\hline Patalase 2000L & $3.4 \pm 0.15^{\mathrm{de}}$ \\
\hline EversaTranform & $3.6 \pm 0.10^{\mathrm{d}}$ \\
\hline L. Rhizomucor miehei & $3.3 \pm 0.10^{\mathrm{e}}$ \\
\hline L. Thermomyces langinosus & $2.3 \pm 0.05^{\mathrm{f}}$ \\
\hline Callera ${ }^{\circledR}$ Trans & $7.1 \pm 0.20^{\mathrm{a}}$ \\
\hline Novozym 40116 & $5.6 \pm 0.15^{\mathrm{b}}$ \\
\hline L. Aspergillus niger & $5.2 \pm 0.10^{\mathrm{c}}$ \\
\hline
\end{tabular}

One unit of lipase activity is defined as the amount of enzyme required to release 1 nanomol $\left(10^{-9} \mathrm{~mol}\right)$ of $\mathrm{p}$ nitrophenyl per minute at $\mathrm{pH} 7.2$ at $37^{\circ} \mathrm{C}$ using p-nitrophenyl acetate as substrate 
Table 2: Ester yield of butyl formate catalyzed by different lipases

\begin{tabular}{l|c}
\multicolumn{1}{c|}{ Immobilized lipase } & Ester yield (\%) \\
\hline L. Candida rugosa & 0 \\
\hline L. Candida antarctica & $66.8 \pm 2.3^{\mathrm{b}}$ \\
\hline L. Candida antarctica (CalB) & $57.5 \pm 1.4^{\mathrm{c}}$ \\
\hline Novozym 435, Candida antarctica & $72.2 \pm 1.9^{\mathrm{a}}$ \\
\hline Novolime & 0 \\
\hline Lipozym TL IM, Thermomyces lanuginosus & 0 \\
\hline Lipozym RM IM, Rhizomucor meihei & 0 \\
\hline \multicolumn{1}{c}{ Free lipase } & Ester yield (\%) \\
\hline Lipozym TL, Mucor meihei & 0 \\
\hline Patalase 2000L & 0 \\
\hline EversaTranform & 0 \\
\hline L. Rhizomucor miehei & 0 \\
\hline L. Thermomyces langinosus & 0 \\
\hline Callera $®$ Trans & $26.8 \pm 2.6$ \\
\hline Novozym 40116 & \\
\hline L. Aspergillus niger & 0 \\
\hline
\end{tabular}

Each value is expressed as mean \pm standard deviation $(n=3)$. Values not followed by the same letter in each line are significantly different at the $0.05 \%$ level (Duncan's test). 
Table 3: Water content of reaction medium in the presence of various amounts of molecular sieves

\begin{tabular}{c|c}
\hline Molecular sieves (mg) & Water content (\%) \\
\hline 0 & $1.191 \pm 0.040^{\mathrm{a}}$ \\
5 & $0.115 \pm 0.015^{\mathrm{b}}$ \\
10 & $0.082 \pm 0.013^{\mathrm{c}}$ \\
15 & $0.053 \pm 0.009^{\mathrm{d}}$ \\
20 & $0.031 \pm 0.008^{\mathrm{e}}$ \\
25 & $0.027 \pm 0.006^{\mathrm{e}}$ \\
\hline
\end{tabular}

Each value is expressed as mean \pm standard deviation $(n=3)$. Values not followed by the same letter in each line are significantly different at the $0.05 \%$ level (Duncan's test). 


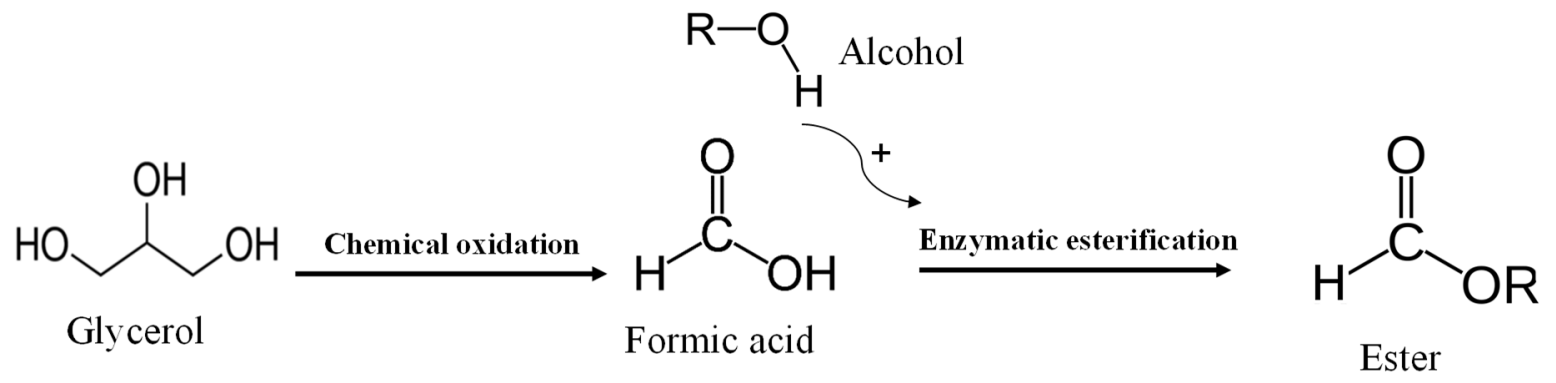

